\title{
Prioritizing Reflection and Integrative Learning in First-Year Seminar Courses
}

\author{
Dianna Z. Rust, Ryan Korstange
}

First-Year Seminar (FYS) or First-Year Experience (FYE) courses help college students transition to college, learn valuable academic skills, and create successful habits. This research analyzes the benefit of reorganizing FYS curriculum around reflection and integrative learning, by comparing students who participated in this redesigned curriculum with those who participated in a skills-based, extended orientation first-year seminar course. The two groups were compared on several measures, including perception about the utility of reflective and integrative thinking, first year retention, and first year GPA. Our findings suggest that prioritizing reflection and integrative learning in a FYS seminar is beneficial.

Keywords: reflection, integrative learning, first year retention, first year seminar, first year experience, freshman retention

A robust First-Year Seminar (FYS) or First-Year Experience (FYE) course is increasingly understood as an essential practice in the effort to retain students and help them take full advantage of their time in college. Three factors combine to demonstrate the significance of these foundational courses. In the first place, despite nearly doubling the number of students in college nationally, the six-year graduation rate remains low - near 59\% (Eaker \& Sells, 2015). Second, public university funding formulas are increasingly shifting towards performance-based funding, even as governmental spending on higher education continues to decline (Nisar, 2015). Finally, by many measures students are increasingly underprepared for college learning at admission and learn less while they are college (Arum \& Roksa, 2011; Blaich \& Wise, 2011). Further, an effective first-year seminar course was recognized by the Association of American Colleges and Universities (AAC\&U) as a high-impact practice - that is, a practice positively correlated both to student learning and to retention (Kuh, 2008).

However, simply offering a FYS course does not make that course high-impact. Rather, effective FYS courses require intentional design. This article details the

Dianna Z. Rust, Ph.D., Middle Tennessee State University Ryan Korstange, Ph.D., Middle Tennessee State University

Author Note:

Financial support was provided by the Faculty Development Grant Committee of Middle Tennessee State University. The authors gratefully acknowledge Faye Johnson for her helpful suggestions and comments. 
theoretical foundation for intentionally structuring a FYS course around student reflection and integrative learning as defined by the AAC\&U's Integrative Learning VALUE Rubric (AAC\&U, 2009). The article further assesses effectiveness of such a design at a large, public, regional university. The course, like many FYS courses, focuses on facilitating student acquisition of effective academic practices and developing student belongingness to the university. The goal of this research is to determine if organizing this FYS course around reflection and integrative thinking abilities produced increases in student engagement at the university and better progression and academic achievement as measured by final course grade and term grade point average.

\section{The Need for a High-Impact FYS}

The first year of college is a period of intense challenge for students (Astin, 1984; Goodman \& Pascarella, 2006; Kidwell, 2005). An intentionally structured first-year experience provides an essential foundation for students' academic success and social satisfaction (Muraskin \& Lee, 2004; Permzadian \& Credé, 2016). FYS courses are created in an effort to assist students as they start building their educational foundation. These courses aim to integrate students into the university culture and to meet the expectations of college-level learning. Recent research suggests that first-year seminar courses are utilized at more than $90 \%$ of fouryear institutions, and at more than $80 \%$ of two-year institutions (Koch, Griffin, \& Barefoot, 2014; Young \& Hopp, 2014). From the institutional perspective, FYS courses play the role of helping students deal with the many challenges that their first year in college presents, such as their increased student autonomy, unfamiliarity with the requirements of college learning, lack of exposure to the socalled hidden curriculum, and underprepared academic skills (Collier \& Morgan, 2008). In general, these courses are aimed at increasing a student's structural and normative integration to the university (Braxton \& Hirschy, 2005) and they also play some role in increasing social engagement (Strayhorn, 2009), without which students may still be at risk (Lotkowski, Robbins, \& Noeth, 2004).

That students need an adequate foundation for their college learning is clear from recent research evaluating what students are learning while in college. For example, Bok (2006) concludes that students are learning in college, but not as much as they should. Arum and Roksa (2011) observe that during the first year and a half of school, $45 \%$ of the 2,300 students they survey demonstrated no improvement in critical thinking. Blaich and Wise (2011), who studied more than 17,000 students at 49 institutions, were concerned with the acquisition of key cognitive abilities including: critical thinking, need for cognition, interest in diversity, attitudes towards diversity, moral reasoning, leadership, and wellbeing. Their study concludes that while the majority of students show moderate improvement in some of the thinking skills they measured, more than one-third of the students studied demonstrate a decline in these cognitive skills. They also point out that most seniors graduate with less academic motivation and openness to diversity than when they started school. Fink (2013) concludes on the basis of 
this study that the problem is the use of ineffective teaching practices; he says, "The basic problem is that, although faculty members want their students to achieve higher kinds of learning, they continue to use teaching practices that are not effective at promoting such learning" (p. 3).

These studies suggest that learning in college is difficult. Students are asked to take in a lot of information - and to learn it independently. There can be no question that an intentionally structured first-year seminar can assist students in navigating the social and academic transitions indicative of the first year in college, and one critical transition is into the college "style" of learning. In this regard, one key realization students need to make is that college learning requires that they regulate themselves and figure out how to learn on their own (Hensley, Wolters, Won, \& Brady, 2018; McCarthy \& Kuh, 2006). Universities are facing increased pressure to retain and graduate students; a high-impact first-year seminar course could play a substantial role in assisting students to make these key transitions and find success in their educational endeavors. The essential question becomes how must a first-year seminar course be structured to ensure its high-impact?

Before an answer to that question can be postulated, it is necessary to consider the standard features of high-impact educational practices. Kuh (2008) identifies several key components of high-impact practices (HIPs). In his view, high-impact activities are those that require students to spend considerable time and effort on educationally significant tasks, and they demand formal and informal conversations between students and between students and faculty about "substantive matters" (p. 14). Though, it is also clear that spending time on tasks does not ensure their educational impact. Further, Kuh suggests that high-impact activities increase "the likelihood that students will experience diversity through contact with people who are different from themselves" (2008, p. 15). These experiences, in turn, challenge students to create new systems or responses as they encounter new tasks inside of and outside of the classroom. High-impact practices also provide a context for frequent feedback - whether formal or informal. In addition, high-impact practices allow students to "integrate, synthesize and apply knowledge" from the classroom into new contexts inside or outside of the college classroom (Kuh, 2008, p. 17). Further research on HIPs expands the list of their characteristics by adding appropriately high-performance expectations, periodic opportunities to reflect and integrate learning, and public demonstrations of competence (Kuh, O'Donnell, \& Reed, 2013). In this way, HIPs increase the likelihood of significant student learning. Skipper (2017) has extrapolated these high-impact practices onto first-year seminar courses, which are themselves a particular subset of the ubiquitous academic seminar.

This research is based on an intentional redesign in the curriculum of our first-year seminar class to incorporate as many of the characteristics of high-impact courses as possible. We found that the best way of incorporating high-impact practices into the first-year seminar class was through a prioritization of reflective and integrative learning (see below for a definition of these terms). Intentional course design of FYS courses is essential. These courses are taught at a critical moment of student transition; and therefore, they need to make use of effective 


\section{Reflection and Integrative Learning}

Organizing a first-year seminar course around the acquisition of student reflection and integrative thinking offers many benefits. Within the context of FYS research, reflection has already been identified as an essential skill for student success (Bader, 2011; Bain, 2012; Cuseo, Fecas, \& Thompson, 2007). In addition, Kuh et al. (2013) include reflection and integration as characteristics of highimpact educational practices. Reflection includes self-assessment, self-monitoring, reflecting on feedback, and reflecting on one's future (Cuseo et al., 2007). Further, reflection contributes to the development of a student's understanding of themselves as a learner and provides them with a method of connecting new challenges with their previous learning and experiences (AAC\&U, 2009). This reflection offers several significant benefits to learners. Reflection slows down learning, helping learners take time to process information and centralize their knowledge. It also helps them develop ownership of the material they are learning. Finally, reflection challenges learning by providing opportunities for students to make order either out of disparate events or out of facing the challenge of discontinuity (Moon, 2004). However, research also indicates that students have difficulty "accurately assessing their own learning and performance, and they fail to adapt their approaches to the current situation" (Ambrose, Bridges, DiPietro, Lovett, \& Norman, 2010, p. 190). Therefore, reflective thinking has a real benefit for students. Given that the first year in college is a time of significant change, self-reflection is an essential tool that students can use to bridge the gap between their knowledge and experience and the institutional requirements. We contend, therefore, that the development of self-reflection and integrative learning in FYS courses will help students make satisfactory academic progress.

The AAC\&U defines integrative thinking as "an understanding and a disposition that a student builds across the curriculum and cocurriculum, from making simple connections among ideas and experiences to synthesizing and transferring learning to new, complex situations within and beyond the campus" (2009, p. 1). Integrative thinking is fundamental to successful learning because it allows for increased discovery, and the application of 'classroom knowledge' to real-world problems (Savery, 2006). It also gives students the opportunity to create connections which aid in making "sense of our complex world" (Humphreys, 2005, p. 30). It is doubtless beyond the scope of a one-semester lower division course to carry the burden of all instruction in integrative thinking, given that larger scale integrative or synthetic work is one desired result of one's entire college career. But, this large-scale integrative thinking is benefited by a first-year seminar that provides a solid foundation for later, more developed, integrative thinking. This foundation can be built by providing students with the opportunity to integrate course content into their other academic classes.

Revising courses around integrative learning and integrative thinking has already been shown to increase persistence and success in STEM majors (Brewer 
\& Smith, 2011; Brophy, 2013; D'Souza, Kroen, Stephens, \& Kashmar, 2015; Gale, 2013). In addition, integrative learning is being incorporated into FYE courses with success at Wagner College (Tooker, Richardson, Preskill, \& Esser, 2014) and Wesley College (D'Souza et al., 2016). The goal of focusing on integrative learning is to clarify "for all stakeholders that in order to get the most out of an undergraduate education, students need to connect, reflect on, and apply learning so that 'the whole becomes more than the sum of the parts'" (Hovland, Anderson, \& Ferren, 2015, p. 4).

There is, in addition, a connection between prioritizing integrative thinking in the first year, and increased gains in integrative thinking through the college experience. As Huber and Hutchings (2004) put it, "When experiences like these [prioritizing integrative thinking] occur in the first year, students may begin to develop habits of connection making" (p. 8). Further, the benefits of integrative thinking extend past individual classes, and onto a student's entire academic experience. As Mahoney and Schamber (2011) state, "integrative learning, from a constructivist perspective, assists students with finding relevance in the curriculum" (p. 236). In addition, integrative learning opportunities facilitate cognitive growth, maturation, and identity formation (Huber \& Hutchings, 2004, p. 237). The benefits of integrative thinking also extend past a student's college career. Huber and Hutchings (2004) point to this benefit by asserting,

students headed for professional careers will still need specialized expertise. But with flexibility and mobility as watchwords in today's economy, few college graduates can expect to spend a whole career with the same employer or even in the same line of work ... the role of interdisciplinary collaboration and exchange is growing both within and outside the academy (p. 5).

These are significant benefits - both for the university and for the student. Thus, infusing principles of reflective and integrative learning into our First-Year seminar course provides a valuable foundation for student academic success and social integration.

\section{Overview of the Redesigned First-Year Seminar Curriculum}

The FYS course to be redesigned is a three-credit hour course designed for first semester freshmen. The principal objectives of the course are to prepare students for the academic rigors of college-level learning and to assist them in their integration into the systems and structures of the university. Drawing on the aforementioned research, our redesign of this curriculum attempted to incorporate intentional, reflective thinking on students' academic process, and to encourage students to integrate academic skills material from the FYS course into the approach they take to learning in their other classes. Functionally, our redesign incorporated the following elements:

Assignments: Formative assessment of student learning was handled through 
regular formal reflective writing assignments. The course included eight one-page reflective writing assignments, each of which required the students to apply a skill being discussed in class into another class, or into an element of their cocurriculum, after which they reflected on what they learned from their application. Formative assessment was also undertaken by regular informal reflection in class, through a reflective exit ticket.

Engagement: Students were required to participate in various events held on campus, and to reflect on what they learned from attending these events. These events included social programming sponsored by the Office of Student Involvement, events and lectures sponsored by academic departments, and various service learning opportunities (either organized by individual classes or by Student Affairs). Attendance at and reflection upon these events enhance social and normative integration. Engagement was also fostered through the intentional learning-centered design of individual class sessions.

Final Project: Summative assessment was conducted via a final portfolio demonstrating how students used various academic skills covered in the class through the semester. In this portfolio, students provided examples of their academic work and reflected on that work by pointing out the connections between their application of the course concepts and the discussions hosted in class and postulating the improvements they want to make in these academic areas for upcoming semesters.

The high impact of this curricular approach is seen from a theoretical level by setting the requirements and benefits of reflective and integrative learning against Kuh et al.'s (2013) eight qualities of high-impact practices.

- Performance levels set at high levels: Reflective and integrative thinking sets performance levels that are high. Reflective thinking engages students in a process of self-evaluation and self-improvement. Integrative thinking encourages students to put skills they are learning in the first-year seminar class into practice in other contexts, both inside and outside of the classroom.

- Significant investment of time and effort: The course was structured around frequent formal and informal reflection. These reflective writing assignments start with the application of curricular content into other contexts. For example, rather than simply explain the benefit of getting involved on campus, this course design assigned student participation in various campus activities, and then asked them to reflect on what they learned from their involvement. Requiring integration of class concepts and reflection on that integration takes time and effort.

- Interaction with faculty and peers about substantive matters: Prioritizing reflective and integrative learning in the first-year seminar classroom provides the means for significant interaction between faculty and 
student and amongst students. In part, by getting students to reflect on their own experiences (both experiences in education, and experiences of applying class concepts to other contexts), the students must first articulate their experience. This articulation provides the 'raw-materials' for all kinds of interaction.

- Frequent feedback: Structuring class around reflective and integrative thinking requires frequent constructive feedback. The redesign we put into practice required eight formal reflective writing assignments, and more informal, in-class reflective thinking. These reflective writing assignments provide the venue for constructive feedback that helps students to acquire a growth mindset and develop academic resilience (Korstange, 2016).

- Periodic, structured reflection and integration: Our redesigned curriculum took this feature as a starting point - incorporating reflection and integration at a high level.

- Opportunities to discover relevance of learning through real-world applications: In part, our course serves to teach students some common academic skills: note-taking, how to read textbooks, how to study, how to write papers, etc. The redesigned curriculum 'uncoupled' the assessment of student mastery of these skills from the first-year seminar class itself, and instead assessed student abilities in these skills through the way in which they apply the skills in other classes and reflect on their use of the skills.

Therefore, the redesigned curriculum which focuses on student development of reflection and integrative learning is, at least theoretically, high impact. The remainder of this article will assess the effectiveness of the curriculum and measure its impact.

\section{Research Questions}

As institutions are considering improving First-Year Seminar course curriculum, it is important to consider current approaches used in FYS that are successful, whether they provide other academic or personal value for students, and whether they provide a unified First-Year Experience. This study examines the persistence and perceptions of students who enrolled in revised sections of our FYS aligned with the University's strategic student success initiatives. The revised approach and curriculum for FYS was piloted in several sections. Based on the pilot, we tested several specific predictions.

First, we predicted that the students would report higher levels of engagement in the redesigned courses (H1). The course and assignments were designed to require significant engagement activities within the first two weeks of the semester and required a course activity that occurred outside of the classroom. Therefore, we expected that students' ratings of engagement would be higher than the other sections.

Our second hypothesis was that students who completed the redesigned courses would report higher levels of making connections and applying their 
learning in FYS content to other courses, disciplines, and prior experiences (H2). The redesigned curriculum intentionally focused on developing integrative learning and reflection both in the class content and assignments. For this reason we supposed that students would recognize these connections and report deeper or more frequent connections on the end of course survey.

Thirdly, we predicted that students in the redesigned course would realize the benefit of reflection and integrative learning for the future (H3). Given the emphasis in the class on integrative learning and reflection in the redesigned sections, we thought that students would be more appreciative of the benefits of this approach than students in the other sections.

Our fourth hypothesis was that students would be more likely to recommend the course to other students if they were in the redesigned course (H4). Our premise was that the emphasis on engagement in and outside the classroom would produce a higher satisfaction rate among students and the likelihood they would recommend the course would increase.

The fifth hypothesis was that students would indicate at a higher level that they grew personally and professionally as a result of completing the redesigned course (H5). Huber and Hutchings (2004) have found that integrative learning opportunities facilitate maturation and identify formation (p. 237). Because of the integrative and reflective nature of the assignments and course, we predicted that the students in the redesigned sections would have investigated their strengths and weaknesses and have a better understanding of their growth over the course of the semester.

Finally, we predicted that students in the redesigned course group would persist to the following fall semester at a higher level. We felt that the changes in the course provided students with a conceptual tool to assess their learning, to improve their academic processes, and therefore to integrate into the university structure more effectively.

\section{Method}

Participants. In Fall 2016, 760 FYS students were asked to complete our survey at the end of the fall semester. Of this group, 405 agreed to participate, and 4 students completed the survey but declined to participate. This was a response rate of $53 \%$. Of those willing to participate, this included 181 students who enrolled in 16 sections of the redesigned course and 220 students who completed the course in one of 24 sections taught in the traditional format. Of those students, 382 provided a valid student ID which allowed for gathering their ACT score, final grade, university term GPA as well as their enrollment status. Three hundred fifteen students in the sample had an ACT score recorded. Their average ACT score was $19.56(S D=3.98)$. The average ACT score of the students in the redesign group was 20.71 as compared to an average ACT score of 18.7 for the traditional course group. The ACT of both groups was lower than the 22.5 average ACT score of the university's freshman class in Fall 2016. An independent-samples t-test was conducted to compare the average ACT score of the redesign course students $(M=$ 
$20.71, S D=4.77)$ and traditional course students $(M=18.7, S D=3.00)$. There was a significant difference in the average ACT scores for the student groups, $t(211)=$ $-4.312, p<.001$. The redesign group had a higher average ACT score.

Procedures and Measures. Participants self-selected their FYS course section during registration. Near the end of the term, students were asked to complete an 18-item online survey. Students were first asked to provide their student identification number. Next, participants rated a wide variety of items pertaining to the FYS course, using a 7-point Likert scale $(1=$ strongly disagree, $7=$ strongly agree $)$. Questions related to student's perceptions of student engagement, reflection, and integrative thinking. Responses were grouped as course redesign participants and traditional course participants depending upon the section the student was enrolled in, and a comparative analysis was conducted.

An email was sent to all of the students in the FYS classes for Fall 2016 informing them of the study. The students were encouraged to email or call the investigators with any questions they had about being included in the study. The email instructed the students to go online and complete the consent form which was linked in the email and then to complete the online survey.

We also compared students in both groups in terms of their progression to the following fall semester and institutional GPA. There were 382 students who provided the correct student ID number and these students were included in this comparison. Data was provided by the institution's Institutional Effectiveness, Research and Planning Office.

\section{Results}

Table 1 provides the major survey measures for both groups. As the table indicates, students in the redesigned course had more positive responses than the students in the traditional course on all measures.

In order to test the research question (H1), we compared the responses from students who completed the redesigned course $(n=181)$ to those who completed it in the traditional format $(n=218)$ on the measure of engagement. Students in the redesigned version reported slightly higher levels of course engagement $(M$ $=5.56, S D=1.53)$ than students in the traditional version of the course $(M=5.37$, $S D=1.91)$. However, there was not a significant difference in the responses from students in the redesigned and traditional course $t(396)=1.084, p=.279$. Thus, we found no support for our first hypothesis.

To test our second hypothesis, we compared the responses from students who completed the redesigned courses $(n=180)$ to those who completed it in the traditional format $(n=220)$ on the measures of relating course activities to course materials, to other courses, to other disciplines, to prior experiences, as well as applying what they were learning. First, students in the redesigned version reported significantly higher levels of relating course activities to course materials $(M=6.36, S D=1.01)$ than students in the traditional version of the course $(M$ $=5.82, S D=1.67) ; t(367)=4.009, p<.001$. Students in the redesigned version also reported higher levels of relating course activities to other courses. There was 


\section{Descriptive Statistics for Major Survey Items \\ (Scale: 1 = strongly disagree, 7 = strongly agree)}

\begin{tabular}{|c|c|c|c|c|c|}
\hline \multirow[b]{3}{*}{ Hypothesis } & \multirow[b]{3}{*}{ Question } & \multicolumn{4}{|c|}{ Course type } \\
\hline & & \multicolumn{2}{|c|}{ Redesigned } & \multicolumn{2}{|c|}{ Traditional } \\
\hline & & $M$ & $S D$ & $M$ & $S D$ \\
\hline $\mathrm{H} 2$ & Q1 Related course activities to course materials & $6.36^{*}$ & 1.01 & 5.82 & 1.67 \\
\hline $\mathrm{H} 2$ & Q2 Related this course to other courses & $6.41 *$ & .99 & 6.07 & 1.44 \\
\hline $\mathrm{H} 2$ & Q3 Made connections to other disciplines & $6.36^{*}$ & 1.01 & 6.05 & 1.43 \\
\hline $\mathrm{H} 2$ & $\begin{array}{l}\text { Q4 Made connections from my prior } \\
\text { experiences }\end{array}$ & $6.35^{*}$ & .92 & 6.08 & 1.35 \\
\hline $\mathrm{H} 2$ & Q6 Applied what I was learning in class & $6.46^{*}$ & .97 & 6.14 & 1.42 \\
\hline H5 & $\begin{array}{l}\text { Q9 Grown personally as a result of being in this } \\
\text { course }\end{array}$ & $5.99 *$ & 1.28 & 5.62 & 1.74 \\
\hline H5 & $\begin{array}{l}\text { Q10 Grown professionally as a result of being in } \\
\text { this course }\end{array}$ & $5.98 *$ & 1.20 & 5.63 & 1.71 \\
\hline H1 & Q12 More engaged in this course & 5.56 & 1.53 & 5.37 & 1.91 \\
\hline H4 & Q13 Recommend this course & 6.08 & 1.31 & 5.83 & 1.76 \\
\hline H3 & $\begin{array}{l}\text { Q14 Reflective thinking is beneficial for the rest } \\
\text { of my education }\end{array}$ & 6.28 & 1.05 & 6.03 & 1.39 \\
\hline H3 & $\begin{array}{l}\text { Q15 Reflective thinking is beneficial for my } \\
\text { career. }\end{array}$ & 6.23 & 1.11 & 6.13 & 1.39 \\
\hline $\mathrm{H} 3$ & $\begin{array}{l}\text { Q16 Integrative thinking is beneficial for my } \\
\text { education. }\end{array}$ & $6.36^{*}$ & .91 & 6.02 & 1.42 \\
\hline $\mathrm{H} 3$ & $\begin{array}{l}\text { Q17 Integrative thinking is beneficial for my } \\
\text { career. }\end{array}$ & $6.33 *$ & .93 & 6.09 & 1.39 \\
\hline
\end{tabular}

$* p<.05$

a significant difference in the redesign group $(M=6.41, S D=.99)$ and students in the traditional version of the course $(M=6.07, S D=1.44) ; \mathrm{t}(387)=2.754, p=$ .006 on this question. Students in the redesigned version reported slightly higher levels of relating course activities to other disciplines $(M=6.36, S D=1.01)$ than students in the traditional version of the course $(M=6.05, S D=1.43)$; this result was significant $t(393)=2.549, p=.01$. Additionally, the redesign group reported slightly higher levels of relating course activities to other experiences $(M=6.35, S D$ $=.92)$ than students in the traditional version of the course $(M=6.08, S D=1.35)$; $t(400)=2.311, p=.02$. Finally, the students in the redesigned version reported slightly higher levels of applying their learning in the course $(M=6.46, S D=.97)$ than students in the traditional version of the course $(M=6.14, S D=1.42)$; $t(387)$ $=2.675, p=.008$. The two groups differed significantly for all of these measures (see Table 1). Thus, we found support for our second hypothesis that students in the redesigned courses would report higher levels of making connections and applying their learning. 
For our third hypothesis, we compared the responses from students who completed the redesigned courses $(n=179)$ to those who completed it in the traditional format $(n=220)$ on items related to the perceived benefit of reflection and integrative thinking. There was only a small difference in the students' perception of the benefits of reflective thinking for future courses and their future career. Students in the redesigned version reported slightly higher perceived benefits of reflection for future courses $(M=6.28, S D=1.05)$ than students in the traditional version of the course $(M=6.03, \mathrm{SD}=1.39) ; t(400)=1.958, p=.051$. They perceived slightly higher benefits for their career $(M=6.23, S D=1.11)$ than students in the traditional version of the course $(M=6.13, S D=1.39)$; $t(399)$ $=.800, p=.424$. However, there was not a statistically significant difference on these questions. There was a significant difference in the students' perception of the perceived benefits of integrative thinking for future courses and their future career. Students in the redesigned version reported higher perceived benefits of integrative thinking for future courses $(M=6.36, S D=.91)$ than students in the traditional version of the course $(M=6.02, S D=1.42) ; t(397)=2.728, p=.007$ and higher benefits for their career $(M=6.33, S D=.93)$ than students in the traditional version of the course $(M=6.09, S D=1.39) ; t(401)=1.962, p=.05$. These results were statistically significant. Therefore, our hypothesis (H3) that students in the redesigned course would see the benefit of reflection and integrative learning for the future was partially supported. Students in the redesigned course perceived benefits for integrative learning for their future courses and their career.

Our fourth hypothesis was that students would be more likely to recommend the course to other students if they were in the redesigned course (H4). We compared the responses from students who completed the redesigned courses $(n=182)$ to those who completed it in the traditional format $(n=220)$ on the survey item asking if they would recommend this course to others. Students in the redesigned version were more likely to recommend the course $(M=6.08, S D=$ $1.31)$ than students in the traditional version of the course $(M=5.83, S D=1.76)$. However, there was not a significant difference in the responses from students in the redesigned and traditional course $t(395)=1.667, p=.096$. Therefore, our fourth hypothesis was not supported.

The fifth hypothesis was that students would indicate at a higher level that they grew personally and professionally as a result of completing the redesigned course (H5). We compared the responses from students who completed the redesigned course $(n=181)$ to those who completed it in the traditional format $(n=219)$ on whether they had grown personally or professionally during the class. Students in the redesigned version reported slightly higher levels of personal growth $(M=5.99$, $S D=1.28)$ than students in the traditional version of the course $(M=5.627, S D$ $=1.74)$. There was a significant difference in the responses from students in the redesigned and traditional course $t(393)=2.46, p=.014$. Students in the redesigned version also reported slightly higher levels of professional growth $(M=5.98, S D=$ $1.20)$ than students in the traditional version of the course $(M=5.63, S D=1.71)$. There was a significant difference in the responses from students in the redesigned and traditional course $t(390)=2.41, p=.016$. Thus, we found support for our fifth 
hypothesis.

Finally, we predicted that students in the redesigned course group would persist at a higher rate to the following fall semester. The following fall $87.5 \%$ (147 out of 168) of the students in the redesigned course sections were still enrolled at the university as compared to $74.6 \%$ (156 of 209) of the students in traditional course sections. Conversely, 25\% (53 of 209) of the students in the traditional course sections were not enrolled at the university the following fall. This suggests that the redesigned section students were more likely to be retained at the university to the next fall semester. In addition, the institutional GPA of both groups was also compared. The average institutional GPA of the students in the redesign group was 3.12 as compared to an average institutional GPA of 2.96 for the traditional course group. For comparison purposes, an independent-samples t-test was conducted to compare the average institutional GPA of the redesign course students $(M=3.12, S D=.692)$ and traditional course students $(M=2.96$, $S D=.86)$. There was not a significant difference in the institutional GPAs for the student groups, $t(375)=1.906, p=.057$.

In summary, areas where there was no significant difference in survey responses between the students in the redesigned FYS courses and students in the traditional courses included questions that asked if they were more engaged in the class (H1), if they would recommend the class to others $(\mathrm{H} 4)$, and if reflective thinking is beneficial (H3). Additionally, although the redesign group had a higher GPA, there was not a significant difference in the students' institutional GPAs after one year of enrollment.

Areas where the students in the redesigned courses responded significantly more positively than the students in the traditional course included relating course activities to course materials, to other courses, to other disciplines, to prior experiences, as well as applying what they were learning (H2). When compared with traditional sections, the students in redesigned sections also responded at a significantly higher level that integrative thinking would benefit them in the future (H3), and that they grew personally and professionally as a result of being in the class (H5). A higher percentage of students in the redesigned course group also returned to the university the following fall semester (H6).

\section{Discussion}

Reflective thinking and integrative learning have been noted to be an essential skill for student success (Cuseo et al., 2007) and are included in the characteristics of high-impact educational practices (Kuh et al., 2013). One goal of this study was to explore the benefits of redesigning a FYS to align with reflective and integrative thinking practices. Survey results provide evidence that aligning an FYS with reflection and integrative learning has several benefits.

Our revised curriculum was more effective at developing students' integrative learning and self-reflection skills, as evidenced by student responses to the questions pertaining to integrative thinking indicators. Students in the redesigned sections related course activities to course materials, to other courses, to other 
disciplines, to prior experiences, as well as applying what they were learning at a significantly higher level. Additionally, students in the redesigned sections saw the long-term benefit of integrative learning, noting that integrative thinking would benefit them in future courses and their career. This provides some evidence that these students would continue to use this approach as they enroll in other courses and in their co-curricular activities, since they realized the advantage of this approach.

The findings of this study suggest that an emphasis in the FYS curriculum on reflection and integrative learning would result in greater perceptions of personal and professional growth among first-year students. Due to the emphasis on selfreflection, students may become more aware of their behaviors and actions and make more frequent adjustments. The reflection component of this FYS followed the reflective model proposed by Rolfe, Freshwater, and Jasper (2001), which has three components: What? a description of the situation; So What? Analysis of the situation through theory and knowledge building; and Now what? a description of ways to improve the situation. Answering this "now what?" question may have resulted in the perceptions of personal and professional growth.

Additionally, the students in the sections with the redesigned curriculum were more likely to return to the university the following fall semester. This finding supports other studies that have found an increase in persistence and success in STEM majors when courses were instructed around integrative learning (Brewer \& Smith, 2011; Brophy, 2013). This finding is promising and should be explored further to see if the retention of these students to the following fall also leads to higher graduation rates. As stated earlier, the redesigned curriculum gives students a conceptual tool of reflection and integrative learning. This conceptual tool can teach them to reflect on and assess their learning and use that assessment to make further adjustments and improvements to their academic processes.

As noted above, further research should explore the impact of this approach over multiple semesters, instead of just one semester, to see if there is a lasting impact in terms of students' applying integrative and reflective thinking in subsequent courses and valuing integrative and reflective thinking. Additionally, further research could compare students in the FYS with an integrative/reflective thinking approach to students who did not participate in an FYS. Since some of the training the FYS faculty receive is similar and the textbook is the same, comparing the FYS redesigned course to a freshman course with different content could provide greater insight to the impact of this approach.

\section{Limitations}

The current study also has several limitations. The current study used a survey developed locally on our campus as part of our Quality Enhancement Plan. The survey tool to measure students' perceptions of reflective and integrative thinking was pilot tested on our campus but has not been utilized outside the campus. Also, the study includes self-reported data, and there are limitations inherent in self-report. Students may interpret the scale points differently, they may not fully 
understand the questions, and may not answer honestly.

Students in the redesigned course sections had a significantly higher average ACT score than the students in the traditional sections. Some of the differences noted in this study between both groups could be attributed to a variance in academic preparation (as defined by ACT scores) between the two groups rather than the change in the integrative and reflective thinking approach taken in this redesign. Interestingly, the institutional GPA of both groups after one year of enrollment was not significantly different.

Data was gathered for this study at the end of a one-semester course. The study does not demonstrate the lasting impact of this approach. As noted above, future research should explore the impact of this approach over multiple semesters to see if there is a lasting impact in terms of students' applying integrative and reflective thinking in subsequent courses and valuing integrative and reflective thinking.

\section{Conclusion and Implications}

This study began as an applied research project to determine the benefit of a redesigned FYS focused on developing a student's reflective and integrative thinking skills. The data revealed that this focused redesigned curriculum was more effective at developing students' integrative thinking and self-reflection skills. Also, the data indicated this approach can have a positive impact on students' personal and professional growth. We feel that this focus on reflective and integrative thinking adds to student retention.

One implication of these findings is the expansion of this reflective and integrative thinking FYS curriculum to all FYS sections offered at the university. From these results, other faculty members should consider this approach, particularly in the first and second-year curriculum. Since reflection and integrative thinking is a process, or "habit of the mind," any improvement in this skill will carry forward to other courses, semesters, and student's professional lives. This study supports the integration of reflection and integrative thinking as a positive tool for students' personal and professional growth.

\section{References}

Ambrose, S. A., Bridges, M., DiPietro, M., Lovett, M., \& Norman, M. (2010). How learning works: seven research-based principles for smart teaching. San Francisco, CA: Jossey-Bass.

Arum, R., \& Roksa, J. (2011). Academically adrift: limited learning on college campuses. Chicago, IL: University of Chicago Press, 2011.

Association of American Colleges and Universities. (2009). Integrative learning VALUE Rubric. Retrieved from https://www.aacu.org/value/rubrics/integrativelearning. 
Astin, A. W. (1984). Student involvement: A developmental theory for Higher Education. Journal of College Student Development, 25(4), 297-308.

Bader, J. B. (2011). Dean's list: Eleven habits of highly successful college students. Baltimore, MD: The Johns Hopkins University Press.

Bain, K. (2012). What the best college students do. Cambridge, MA: Belknap Press of Harvard University Press.

Blaich, C. F., \& Wise, K. S. (2011, January). From gathering to using assessment results: Lessons from the Wabash National Study. (NILOA Occasional Paper No. 8). Urbana, IL: University of Illinois and Indiana University, National Institute for Learning Outcomes Assessment.

Bok, D. C. (2006). Our underachieving colleges: A candid look at how much students learn and why they should be learning more. Princeton, NJ: Princeton University Press.

Braxton, J. M., \& Hirschy, A. S. (2005). Theoretical developments in the study of college student departure. In A. Seldman, (Ed.), College student retention: Formula for student success (pp. 61-87). Westport, CT: ACE Praeger.

Brewer, C., \& Smith, D. (Eds.). (2011). Vision and change in undergraduate biology education: A call to action. Washington, D.C.: American Association for the Advancement of Science. Retrieved from http://visionandchange.org/ files/2011/03/Revised-Vision-and-Change-Final-Report.pdf

Brophy, J. E. (2013). Motivating students to learn. New York: Routledge.

Collier, P. J., \& Morgan, D. L., (2008). "Is that paper really due today?": Differences in first-generation and traditional college students' understandings of faculty expectations. Higher Education: The International Journal of Higher Education and Educational Planning, 55(4), 425-446.

Cuseo, J., Fecas, V. S., \& Thompson, A. (2007). Thriving in college and beyond: Research based strategies for academic success and personal development. Dubuque, IA: Kendall/Hunt.

D'Souza, M. J., Curran, K. L., Olsen, P. E., Nwogbaga, A. P., \& Stotts, S. (2016). Integrative approach for a transformative freshman-level STEM curriculum. Journal of College Teaching and Learning, 13(2), 47-64.

D'Souza, M. J., Kroen, W. K., Stephens, C. B., \& Kashmar, R. J. (2015). Strategies and initiatives that revitalize Wesley College STEM programs. Journal of College Teaching and Learning, 12(3), 195-208.

Eaker, R. E., \& Sells, D. (2015). A new way: Introducing higher education to professional learning communities at work. Bloomington, IN: Solution Tree Press.

Fink, L. D. (2013). Creating significant learning experiences: an integrated approach to designing college courses. San Francisco, CA: Jossey-Bass.

Gale, R. A. (2013). Pedagogies of integration. In T. A. Ferrett, D. R. Geelan, W. M. Schlegel, and J. L. Stewart (Eds.), Connected science: Strategies for integrative learning in college (pp. 117-140). Bloomington, IN: Indiana University Press.

Goodman, K., \& Pascarella, E. T. (2006). First-year seminars increase persistence and retention: A summary of the evidence from how college affects students. Peer Review, 8(3), 26-28. 
Hensley, L. C., Wolters, C. A., Won, S., \& Brady, A. C. (2018) Academic probation, time management, and time use in a college success course. Journal of College Reading and Learning, 48(2), 105-123.

Hovland, K., Anderson, C. B., \& Ferren, A. S. (2015). Interrogating integrative learning. Peer Review, 16(4)/17(1), 4-6.

Huber, M. T., \& Hutchings, P. (2004). Integrative learning: Mapping the terrain. The academy in transition. Washington, D.C.: Association of American Colleges and Universities.

Humphreys, D. (2005). Why integrative learning? Why now? Peer Review, 7(4), 3031.

Kidwell, K. S. (2005). Understanding the college first-year experience. The Clearing House: A Journal of Educational Strategies, Issues, and Ideas, 78(6), 253-255.

Koch, S. S., Griffin, B. Q., \& Barefoot, B. O. (2014). National survey of student success initiatives at two-year colleges. Brevard, NC: John Gardner Institute for Excellence in Undergraduate Education. Retrieved from http://www.jngi.org/wordpress/ wp-content/uploads/2014/07/National-2-yr-Survey-Booklet_webversion.pdf

Korstange, R. K. (2016). Developing growth mindset through reflective writing. Journal of Student Success and Retention, 3(1), 1-26.

Kuh, G. D. (2008). High-impact educational practices: What they are, who has access to them, and why they matter. Washington, DC: Association of American Colleges and Universities.

Kuh, G. D., O'Donnell, K., Reed, S. D. (2013). Ensuring quality \& taking high-impact practices to scale. Washington, D.C.: Association of American Colleges and Universities.

Lotkowski, V. A., Robbins, S. B., \& Noeth, R. J. (2004). The role of academic and nonacademic factors in improving college retention. ACT Policy Report. Retrieved from https://files.eric.ed.gov/fulltext/ED485476.pdf

Mahoney, S., \& Schamber, J. (2011). Integrative and deep learning through a learning community: A process view of self. Journal of General Education, 60(4), 234-247. doi: 10.5325/igeneeduc.60.4.0234

McCarthy, M., \& Kuh, G. D. (2006). Are students ready for college?

What student engagement data say. Phi Delta Kappan, 87, 664-669. doi:10.1177/003172170608700909

Moon, J. A. (2004). A handbook of reflective and experiential learning: Theory and practice. London: Routledge-Falmer.

Muraskin, L. D., Lee, J. (with Wilner, A., \& Swail, W. S.). (2004). Raising the graduation rates of low-income college students. Washington, D.C.: Pell Institute for the Study of Opportunity in Higher Education.

Nisar, M. A. (2015). Higher education governance and performance based funding as an ecology of games. Higher Education, 69(2), 289-302. https://doi. org $/ 10.1007 / \mathrm{s} 1073$

Permzadian, V., \& Credé, M. (2016). Do First-Year seminars improve college grades and retention? A quantitative review of their overall effectiveness and an examination of moderators of effectiveness. Review of Educational Research, 86(1), 277-316. doi: 10.3102/0034654315584955 
Rolfe, G., Freshwater, D., \& Jasper, M. (2001). Critical reflection in nursing and the helping professions: A user's guide. Basingstoke, England: Palgrave Macmillan.

Savery, J. R. (2006). Overview of problem-based learning: Definitions and distinctions. In A. Walker, H. Leary, C. Hmelo-Silver, \& P.A. Ertmer (Eds.), Essential readings in problem-based learning: Exploring and extending the legacy of Howard S. Barrows (pp. 5-16). West Lafayette, IN: Purdue University Press.

Skipper, T. L. (2017). What makes the first-year seminar high impact? An exploration of effective educational practices. Columbia, SC: University of South Carolina, National Resource Center for the First-Year Experience and Students in Transition.

Strayhorn, T. L. (2009). An examination of the impact of first-year seminars on correlates of college student retention. Journal of the First-Year Experience \& Students in Transition, 21(1), 9-27.

Tooker, P., Richardson, N., Preskill, S., \& Esser, J. (2014). Integrative learning in the first-year program. Peer Review, 16(4), 12.

Young, D. G., \& Hopp, J. M. (2014). 2012-2013 National survey of first-year seminars: Exploring high-impact practices in the first college year. Columbia, SC: University of South Carolina, National Resource Center for the First-Year Experience and Students in Transition. 